\title{
Komunikasi Stakeholder pada Kegiatan Kaji Terap Budidaya Padi Toleran Salinitas di BPTP Jawa Barat
}

\section{Communication of Stakeholder on The Applied Study of Salinity Tolerant Paddy Cultivation at BPTP West Java}

\author{
Dini Fibriyanti $^{1, *)}$, Dwi Sadono ${ }^{2}$, Sarwititi Sarwoprasodjo ${ }^{2}$
}

${ }^{1}$ Balai Pengkajian Teknologi Pertanian Maluku, Ambon 97233, Indonesia

${ }^{2}$ Departemen Sains Komunikasi dan Pengembangan Masyarakat, IPB University, Bogor 16680, Indonesia

${ }^{*}$ E-mail korespondensi: dini.fibriyan@gmail.com

Diterima: 24 November 2020 | Disetujui: 21 April 2021 | Publikasi Online: 3 Mei 2021

\begin{abstract}
The success of the applied study can be achieved if the cooperation and coordination between stakeholder goes well so that there is an acceleration of the spread of innovation and the sustainable adoption of agricultural innovations. The study aims to analyze the correlation between the characteristics of the communication and database media, the characteristics of individual, and the actions of collective and social networks with the effectiveness of stakeholder communication on the applied study of salinity tolerant paddy cultivation. The study was conducted on February-March 2020 in BPTP West Java and Pangandaran Regency. Determination of the respondents carried out by using census method with a total of 33 people. The analysis using Ucinet 6 and rank Spearman correlation test. The results showed the variables that have a significant correlation with effectiveness of stakeholder communication for satisfaction in the process are characteristics of communication and database media includes the availability of infrastructure and facilities, and the amount of media communication, and variable of individual characteristics, it is the formal education, significant correlation for quality of information are social networks variables, there are density and closeness centrality
\end{abstract}

Keywords: Effectiveness of communication, salinity tolerant paddy, stakeholder communication, the applied study

\begin{abstract}
ABSTRAK
Keberhasilan kegiatan kaji terap dapat tercapai jika kerja sama dan koordinasi antara pemangku kepentingan (stakeholder) terkait berjalan baik sehingga terjadi percepatan penyebaran inovasi dan keberlanjutan adopsi inovasi pertanian. Penelitian ini bertujuan untuk menganalisis hubungan antara karakteristik media komunikasi dan media penyimpanan data, karakteristik individu wakil organisasi, proses aksi bersama dan jaringan sosial dengan efektivitas komunikasi stakeholder pada kegiatan kaji terap budidaya padi salin. Penelitian dilaksanakan pada bulan Februari-Maret 2020 di BPTP Jawa Barat dan Kabupaten Pangandaran. Metode penentuan responden melalui sensus dengan jumlah 33 orang. Analisis data menggunakan Ucinet 6 dan uji korelasi rank Spearman secara deskriptif. Hasil penelitian menunjukkan variabel-variabel yang berhubungan nyata dengan efektivitas komunikasi stakeholder untuk kepuasan dalam proses komunikasi adalah karakteristik media komunikasi dan media penyimpanan data, meliputi tingkat ketersediaan sarana dan prasarana pendukung, dan jumlah penggunaan media komunikasi, dan variabel karakteristik individu, yaitu tingkat pendidikan formal. Variabel yang berhubungan nyata dengan efektivitas komunikasi stakeholder untuk kualitas informasi adalah jaringan sosial, yaitu kepadatan jaringan dan sentralitas kedekatan
\end{abstract}

Kata kunci: Efektivitas komunikasi, kaji terap, komunikasi stakeholder, padi toleran salinitas

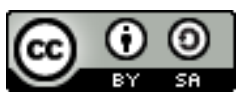




\section{PENDAHULUAN}

Pada Rencana Strategis Badan Penelitian dan Pengembangan Pertanian (Renstra Balitbangtan) Tahun 2015-2019 disebutkan bahwa hasil-hasil penelitian Balitbangtan masih memerlukan akselerasi pemasyarakatan inovasi melalui kegiatan pengkajian dan diseminasi teknologi pertanian. Hal ini terkait dengan salah satu isu pembangunan pertanian yang menyebutkan bahwa belum optimalnya pemenuhan kebutuhan inovasi dalam mendukung pembangunan pertanian wilayah dan masih lambannya pemasyarakatan inovasi pertanian hasil-hasil dari litbang pertanian (Balitbangtan, 2015). Inovasi teknologi yang dihasilkan oleh Badan Penelitian dan Pengembangan Pertanian (Balitbangtan) banyak yang belum diadopsi dengan baik dan pada skala luas. Segmen rantai pasok inovasi pada subsistem penyampaian (delivery subsystem) dan subsistem penerima (receiving subsystem) merupakan bottleneck yang menjadi penyebab lambannya penyampaian informasi dan rendahnya tingkat adopsi inovasi yang dihasilkan Balitbangtan (Sarwani et al., 2011; Syakir, 2016). Lebih lanjut Sarwani et al. (2011) mengungkapkan bahwa pembelajaran yang dapat diambil dari pelaksanaan berbagai kegiatan/program yang terkait dengan diseminasi selama ini adalah masih lemahnya communication in linkages antara para pemangku kepentingan/stakeholder, mulai dari Balai Penelitian (Balit) dan Balai Pengkajian Teknologi Pertanian (BPTP) maupun antara BPTP dengan stakeholder di lapangan (petani, dinas, NGO, PPL). Upaya mencapai target pembangunan pertanian banyak menghadapi masalah bukan pada kemiskinan teknologi melainkan hambatan pada proses mengomunikasikan dan menghantarkan teknologi dari sumber kepada penerima (Tarigan et al., 2016).

Penelitian Indraningsih (2011) menunjukkan bahwa kecepatan dan tingkat pemanfaatan inovasi teknologi yang dihasilkan Balitbangtan cenderung lambat, bahkan menurun. Inovasi teknologi usaha tani terpadu yang telah diperkenalkan belum sepenuhnya diadopsi oleh seluruh petani yang tinggal di lahan pertanian marjinal karena proses penyampaian inovasi teknologi dari penyuluh BPTP Jawa Barat dan penyuluh BPP kepada petani lebih bersifat searah. Petani hanya diberi dan menerima suatu inovasi teknologi, tidak dilibatkan dalam setiap perencanaan dan pengambilan keputusan yang berkaitan dengan usaha taninya. Tarigan et al. (2016) juga menemukan bahwa sistem komunikasi sosialisasi dan pemanfaatan varietas unggul baru padi toleran rendaman (VUB-PTR) merupakan komunikasi berjenjang dengan model linier, sifatnya searah, tidak ada ruang untuk menyampaikan umpan balik, metode dan alat komunikasi dirancang sepihak oleh sumber dan disampaikan menurut budaya sumber yang berbeda dengan budaya penerima sehingga proses adopsi menjadi lambat.

Keterpaduan antara subsistem pengadaan/penciptaan (generating subsystem), subsistem penyampaian (delivery subsystem), dan subsistem penerima (receiving subsystem) inovasi teknologi harus terwujud dalam sistem inovasi pertanian agar inovasi teknologi dapat diterima dan diadopsi oleh pengguna (Sarwani et al., 2011; Syakir, 2016). Hal ini menunjukkan bahwa pentingnya peran komunikasi dalam kegiatan diseminasi inovasi teknologi untuk menjalankan program pembangunan pertanian karena sebagai saluran informasi dari pemerintah (penyedia inovasi) kepada masyarakat (pengguna inovasi) untuk menyukseskan tujuan pembangunan. Upaya Balitbangtan dalam mempercepat dan memassalkan diseminasi informasi dan inovasi pertanian pada tahun 2011 telah merancang sebuah model yang mampu menjangkau stakeholder secara luas dengan memanfaatkan berbagai media dan saluran komunikasi yang sesuai dengan karakteristik masing-masing stakeholder, dikenal dengan nama Spectrum Diseminasi Multi Channel (SDMC). SDMC yaitu suatu terobosan untuk mempercepat dan memperluas jangkauan diseminasi dengan memanfaatkan berbagai saluran komunikasi dan stakeholder terkait secara optimal melalui berbagai media secara simultan dan terkoordinasi (Kallo \& Sariubang, 2013).

Efektivitas penerapan SDMC dalam pelaksanaan kegiatan diseminasi inovasi pertanian dapat tercapai jika kerja sama dan koordinasi antara stakeholder terkait berjalan baik dengan memanfaatkan berbagai saluran informasi. Keberadaan BPTP sebagai unit pelaksana teknis dari Balitbangtan di provinsi, sejak awal dimaksudkan sebagai jembatan yang menghubungkan kegiatan penelitian dan penyuluhan, melalui diseminasi hasil penelitian kepada penyuluh dan atau pengguna lainnya dengan menyebarluaskan informasi dan teknologi pertanian spesifik lokasi, seperti pada kegiatan kaji terap budidaya padi toleran salinitas yang dilaksanakan oleh BPTP Jawa Barat. Kaji terap adalah uji coba 
teknologi yang dilakukan oleh pelaku utama untuk meyakinkan keunggulan teknologi anjuran dibandingkan teknologi yang pernah diterapkan kepada pelaku utama lainnya di lahan milik petani/BPP yang pelaksanaannya dilakukan secara koordinatif dan partisipatif bersama stakeholder terkait (BBP2TP, 2018).

Kegiatan diseminasi inovasi pertanian yang dilakukan BPTP dengan pendekatan model SDMC selama ini hanya fokus dalam memanfaatkan berbagai media komunikasi dan stakeholder terkait. Faktor lain yang belum menjadi perhatian, tetapi juga menjadi faktor kunci yang menentukan efektivitas komunikasi antarstakeholder, yaitu jaringan sosial, seperti yang dikemukakan oleh Monge et al. (1998). Analisis jaringan sosial dapat membantu mengidentifikasikan individu-individu yang dianggap paling penting dalam sebuah jaringan sosial pada kegiatan diseminasi inovasi teknologi. Model sistem informasi dan komunikasi antarorganisasi berbasis aliansi yang disusun oleh Monge et al. (1998) berdasarkan teori barang publik dari Marwell dan Oliver menggambarkan bahwa faktor kunci yang menentukan efektivitas komunikasi antarorganisasi, terdiri dari: 1) Karakteristik media komunikasi dan penyimpanan data; 2) Karakteristik partisipan; 3) Karakteristik kelompok; 4) Proses aksi bersama dan jaringan sosial. Oleh karena itu, penting dilakukan penelitian tentang komunikasi antarstakeholder pada kegiatan kaji terap budidaya padi toleran salinitas dengan mengacu pada model sistem informasi dan komunikasi antarorganisasi berbasis aliansi dari Monge et al. (1998). Tujuan penelitian ini adalah menganalisis hubungan antara karakteristik media komunikasi dan penyimpanan data, karakteristik individu wakil organisasi, dan proses aksi bersama dan jaringan sosial dengan efektivitas komunikasi antara stakeholder pada kegiatan kaji terap budidaya padi toleran salinitas. Hasil penelitian diharapkan dapat memberikan kontribusi kepada stakeholder terkait untuk menyusun strategi komunikasi pembangunan yang tepat agar terjadi percepatan penyebaran inovasi dan keberlanjutan adopsi inovasi pertanian.

\section{METODE PENELITIAN}

Penelitian ini didesain sebagai penelitian yang bersifat deskriptif korelasional, untuk mendapatkan fakta dari gejala-gejala yang ada dan mencari keterangan secara faktual. Penelitian ini menggunakan data kuantitatif dan kualitatif yang berusaha untuk menjelaskan serta menguraikan fakta dan fenomena yang diamati. Pengumpulan data dilakukan dari bulan Februari sampai Maret 2020. Data dikumpulkan melalui pengamatan, mengajukan kuesioner dan wawancara mendalam. Pengamatan, yaitu melakukan observasi langsung ke lokasi penelitian untuk mengetahui lokasi penelitian. Kuesioner yang disebarkan terdiri dari beberapa bagian pertanyaan dan pernyataan mengenai karakteristik media komunikasi dan penyimpanan data, karakteristik individu wakil organisasi, proses aksi bersama dan jaringan sosial, dan efektivitas komunikasi stakeholder. Wawancara mendalam (indepth interview), yaitu melakukan tanya jawab lisan secara langsung dan mendalam kepada responden guna menggali informasi yang telah diperoleh sebelumnya dari kuesioner.

Data kuantitatif didukung dengan analisis statistik deskriptif dan inferensial. Data kualitatif digunakan untuk menjelaskan efektivitas komunikasi antarstakeholder pada kegiatan kaji terap budidaya padi toleran salinitas di BPTP Jawa Barat. Gambaran dari efektivitas komunikasi antarstakeholder pada kegiatan kaji terap budidaya padi toleran salinitas di BPTP Jawa Barat dijelaskan melalui hubungan atau korelasi dalam variabel penelitian. Variabel yang diteliti dalam penelitian ini yaitu: karakteristik media komunikasi dan penyimpanan data $\left(\mathrm{X}_{1}\right)$, karakteristik individu wakil organisasi $\left(\mathrm{X}_{2}\right)$, proses aksi bersama dan jaringan sosial $\left(\mathrm{X}_{3}\right)$, dan efektivitas komunikasi stakeholder $\left(\mathrm{Y}_{1}\right)$.

Data yang diperoleh pada penelitian diakumulasikan dan disusun secara sistematis untuk kemudian dianalisis dengan menggunakan teknik-teknik analisis data meliputi: analisis statistik deskriptif untuk menganalisis data dan hasil pengamatan dari variabel-variabel yang diteliti, analisis sosiometri digunakan untuk melihat jaringan komunikasi yang terjadi antara stakeholder menggunakan Program Ucinet 6 untuk menganalisis kepadatan dan sentralitas jaringan dan analisis statistik inferensial menggunakan analisis uji korelasi rank Spearman dengan aplikasi SPSS versi 22 untuk mengukur hubungan variabel yang diteliti. Koefisien korelasi rank Spearman dapat digunakan untuk mengukur korelasi atau kaitan antara dua variabel yang memiliki skala paling sedikit ordinal (Silalahi, 2015). 
Penentuan lokasi dilakukan secara purposif dengan pertimbangan bahwa kegiatan diseminasi inovasi pertanian di BPTP Jawa Barat dinilai berhasil oleh Balai Besar Pengkajian dan Pengembangan Teknologi Pertanian (BB Pengkajian) sebagai pembina dari BPTP melalui kegiatan kaji terap budidaya padi varietas toleran salinitas (Inpari 34 salin agritan). Keberhasilan tersebut karena adanya pengembangan kegiatan lanjutan yang dilakukan secara mandiri oleh petani kooperator dan non kooperator di wilayah lingkup lokasi kaji terap seluas 85 hektar. Responden penelitian diambil secara sensus karena terkait dengan salah satu variabel yang dianalisis yaitu jaringan sosial. Sensus adalah menyebutkan satu per satu dari suatu keseluruhan populasi (Silalahi, 2015). Populasi pada penelitian ini adalah seluruh stakeholder yang terlibat dalam kegiatan kaji terap budidaya padi varietas toleran salinitas (Inpari 34 salin agritan), yaitu Dinas Pertanian Kabupaten Pangandaran, BPP Kecamatan Parigi, BPTP Jawa Barat, Kelompok Tani Sri Mukti. Jumlah responden sebanyak 33 orang, terdiri dari dua orang dari Dinas Pertanian Kabupaten Pangandaran, lima orang dari BPP Kecamatan Parigi, delapan orang dari BPTP Jawa Barat, dan 18 orang dari Kelompok Tani Sri Mukti.

\section{HASIL DAN PEMBAHASAN}

\section{Kaji Terap Budidaya Padi Toleran Salinitas di BPTP Jawa Barat}

Kaji Terap merupakan kegiatan uji paket/komponen teknologi di lahan petani/BPP sebagai wahana untuk membuktikan dan menyakinkan bahwa paket/teknologi tersebut sesuai dengan kebutuhan spesifik di lokasi kajian, sekaligus sebagai wahana pembelajaran bersama bagi peneliti, penyuluh pertanian, dan petani. Paket/komponen teknologi yang dikaji terap adalah teknologi yang dibutuhkan oleh daerah, meningkatkan kinerja usaha tani, memberikan dampak yang luas mendukung program strategis Kementan. Hasil kaji terap diharapkan penyuluh pertanian dan petani mau dan mampu menerapkan teknologi. Tujuan pelaksanaan kaji terap adalah meyakinkan pengguna terhadap teknologi melalui peragaan dan uji coba teknologi secara langsung. Peserta kaji terap adalah penyuluh pertanian (penyuluh PNS dan THL-TBPP) dan petani. Kegiatan peningkatan komunikasi, koordinasi dan diseminasi hasil inovasi teknologi di Jawa Barat dilaksanakan secara partisipatif dengan melibatkan Dinas Pertanian, UPTD, dan Penyuluh, sebagai mitra kegiatan. Penyuluh desa dilibatkan langsung dalam pelaksanaan kegiatan mulai dari perencanaan sampai pelaksanaan termasuk dalam pengamatan. Hal ini dilakukan untuk mempermudah adopsi dari teknologi inovasi yang diintroduksikan, yaitu kaji terap inovasi teknologi budidaya padi toleran salinitas. Kaji terap budidaya padi salin dilaksanakan pada lahan sawah lingkup wilayah kerja BPP Kecamatan Parigi Kabupaten Pangandaran dengan luas lima hektar di lahan milik anggota Kelompok Tani Sri Mukti, Dusun Sucen, Desa Cibenda, Kecamatan Parigi, Kabupaten Pangandaran, dengan menggunakan varietas Inpari 34 Salin Agritan. Usaha tani pada kaji terap padi toleran salinitas memiliki prospek yang cukup bagus. Secara agregat, produksi usaha tani padi eksisting (petani) lebih rendah dibandingkan produksi usaha tani padi pada kegiatan kaji terap (Prawiranegara, 2019).

\section{Karakteristik Media Komunikasi dan Penyimpanan Data}

Indikator untuk mengetahui karakteristik media komunikasi dan penyimpanan data dalam penelitian ini, yaitu: tingkat ketersediaan sarana dan prasarana pendukung komunikasi, dan jumlah penggunaan media komunikasi. Hasil penelitian menunjukkan bahwa peserta kegiatan kaji terap budidaya padi toleran salinitas menggunakan berbagai media komunikasi untuk komunikasi langsung, antara lain surat, handphone, whatsapp, dan forum pertemuan. Media komunikasi untuk menyebarkan informasi inovasi pada kegiatan kaji terap budidaya padi toleran salinitas adalah media cetak, media elektronik, media sosial dan forum pertemuan. Media cetak yang digunakan oleh peserta kegiatan kaji terap budidaya padi salin adalah: petunjuk teknis, folder, brosur, dan banner. Media elektronik yang digunakan adalah: handphone, powerpoint, dan video. Media sosial yang digunakan adalah whatsapp.

Media komunikasi berupa folder, banner, brosur, powerpoint, video, dan whatsapp hanya digunakan oleh peserta dari instansi pemerintah, yaitu BPTP Jawa Barat, Dinas Pertanian Kabupaten Pangandaran, dan BBP Kecamatan Parigi. Media cetak berupa petunjuk teknis, folder, brosur dan media eletronik, berupa powerpoint dan video digunakan sebagai sumber informasi bagi peserta dari instansi pemerintah yang kemudian informasi tersebut disampaikan kepada seluruh peserta kegiatan kaji terap melalui forum pertemuan. Banner digunakan untuk menginformasikan tentang kegiatan kaji

Jurnal Penyuluhan | Vol. 17 (01) 2021 | 88 
terap budidaya padi toleran salinitas yang dipasang di lokasi demplot. Penggunaan handphone lebih banyak digunakan untuk percakapan lisan untuk koordinasi antarstakeholder, komunikasi via SMS tidak pernah dilakukan walaupun tersedia. Telepon seluler (handphone) yang dimiliki petani peserta kegiatan kaji terap budidaya padi toleran salinitas adalah handphone biasa yang bukan smartphone, sehingga petani peserta kegiatan kaji terap budidaya padi toleran salinitas juga tidak menggunakan media sosial, seperti whatsapp untuk berkomunikasi di antara mereka. Media sosial whatsapp hanya digunakan oleh peserta dari instansi pemerintah untuk koordinasi dan laporan kegiatan. Media penyimpanan data yang dapat diakses oleh seluruh peserta kegiatan kaji terap budidaya padi toleran salinitas belum tersedia.

Sarana prasarana pendukung untuk komunikasi langsung dan jenis media komunikasi untuk menyebarkan informasi inovasi yang paling sering digunakan dalam kegiatan kaji terap budidaya padi toleran salinitas adalah komunikasi tatap muka melalui forum pertemuan. Komunikasi tatap muka menjadi media yang paling efektif digunakan dalam kegiatan kaji terap budidaya padi toleran salinitas. Hal ini juga dikarenakan dalam kegiatan kaji terap perlu dilakukan praktik langsung di lapangan untuk mendiseminasikan inovasi dari BPTP Jawa Barat dan melihat kondisi perkembangan tanaman secara langsung pada demplot di lahan petani kooperator. Forum pertemuan digunakan untuk sosialiasi kegiatan kaji terap budidaya padi toleran salinitas, bimbingan teknis, temu lapang, dan temu teknis.

\section{Karakteristik Individu}

Karakteristik individu dalam penelitian ini terdiri dari lima indikator yaitu: tingkat ketertarikan, tingkat pendidikan formal, pendidikan non formal, jumlah jenis informasi, dan biaya akses komunikasi yang dikeluarkan. Tingkat ketertarikan adalah keinginan atau tujuan yang ingin dicapai oleh individu wakil organisasi (BPTP, Dinas Pertanian, BPP, kelompok tani) sehingga bersedia memberikan kontribusi sumber daya yang dimiliki. Tingkat ketertarikan dalam memberikan atau menyumbangkan dukungan input (lahan, benih, pupuk, obat-obatan, peralatan, dan lainnya) dari Gambar 1 menunjukkan bahwa paling banyak peserta kegiatan kaji terap budidaya padi toleran salinitas bersedia memberikan kontribusi sumber daya yang dimiliki mayoritas karena ingin memeroleh informasi atau pengalaman dan berbagi informasi.

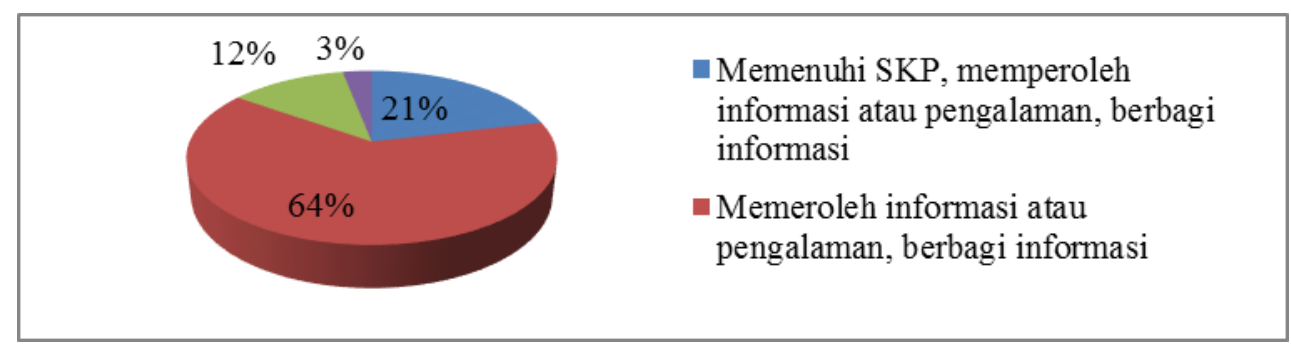

Gambar 1. Persentase peserta menurut tingkat ketertarikan memberikan dukungan input pada kegiatan kaji terap budidaya padi toleran salinitas tahun 2019

Hasil penelitian pada Gambar 2 menunjukkan bahwa jenjang pendidikan formal yang ditempuh peserta kegiatan kaji terap budidaya padi toleran salinitas adalah mulai dari SD, SMP, SMA, D-3, D4/S-1, S-2, dan S-3. Peserta yang memiliki tingkat pendidikan tinggi (perguruan tinggi) lebih sedikit dari yang tidak berpendidikan tinggi, yaitu sebanyak 15 orang atau 45 persen dan mereka merupakan individu wakil dari instansi pemerintah (Dinas Pertanian, BPP, dan BPTP). Sisanya sebanyak 18 orang atau 55 persen merupakan petani kooperator yang tidak berpendidikan tinggi, yaitu pendidikan dasar (SD dan SMP), pendidikan menengah (SMA) dan yang tidak pernah menempuh pendidikan formal.

Pendidikan non formal dalam penelitian ini adalah jumlah pelatihan terkait budidaya padi yang pernah diikuti oleh peserta kegiatan kaji terap budidaya padi toleran salinitas. Hasil penelitian pada Gambar 3 menunjukkan bahwa peserta kegiatan kaji terap budidaya padi salin sebagian besar belum pernah mengikuti pelatihan terkait budidaya padi, yaitu sebanyak 19 orang (58 persen) yang didominasi oleh 
petani kooperator sebanyak 15 orang, kemudian dari Dinas Pertanian dan BPTP masing-masing dua orang. Peserta yang sudah pernah mengikuti pelatihan hanya 14 orang (42 persen) saja.

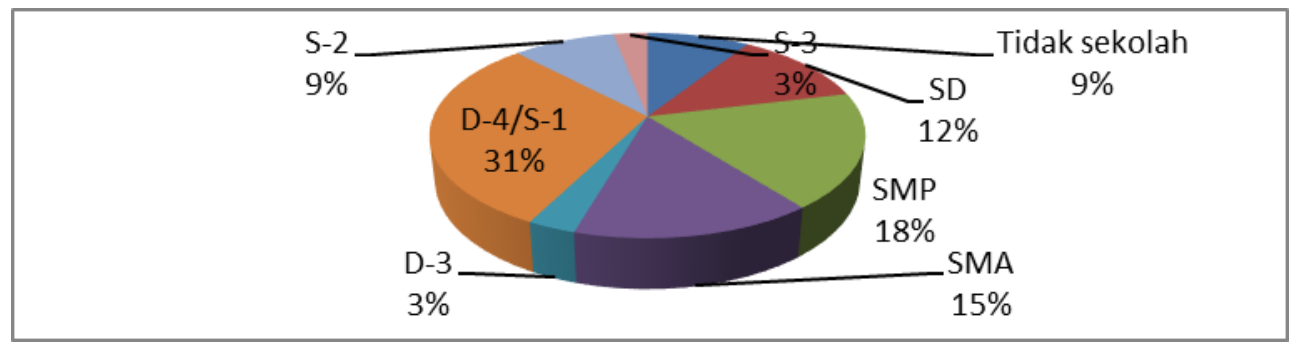

Gambar 2. Persentase peserta menurut tingkat pendidikan formal pada kegiatan kaji terap budidaya padi toleran salinitas tahun 2019

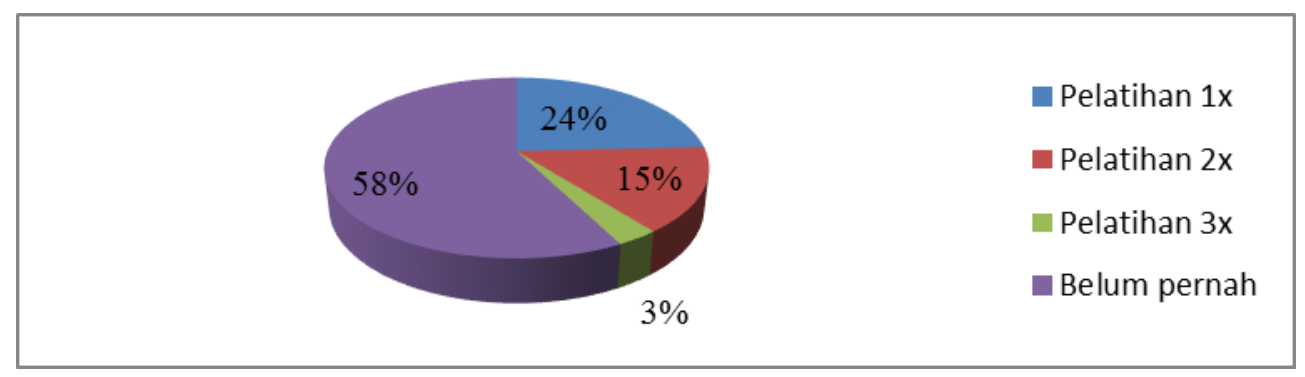

Gambar 3. Persentase peserta menurut pendidikan non formal pada kegiatan kaji terap budidaya padi toleran salinitas tahun 2019

Informasi yang dikontribusikan oleh peserta kegiatan kaji terap budidaya padi salin antara lain penentuan calon petani dan calon lahan (CPCL), teknik budidaya padi salin, penggunaan benih VUB, pembuatan biochar, cara pemupukan, pengairan/pencucian sawah, pengendalian hama dan penyakit, pertumbuhan tanaman, dan analisis usaha tani. Hasil penelitian pada Gambar 4 menunjukkan bahwa sebagian besar peserta kegiatan kaji terap ikut berkontribusi dalam memberikan informasi atau pengetahuannya selama kegiatan berlangsung. Jumlah peserta kegiatan kaji terap yang ikut berkontribusi dalam memberikan informasi atau pengetahuannya selama kegiatan berlangsung sebanyak 20 orang (60 persen), sedangkan yang tidak ikut berkontribusi berjumlah 13 orang (40 persen) yang merupakan petani kooperator.

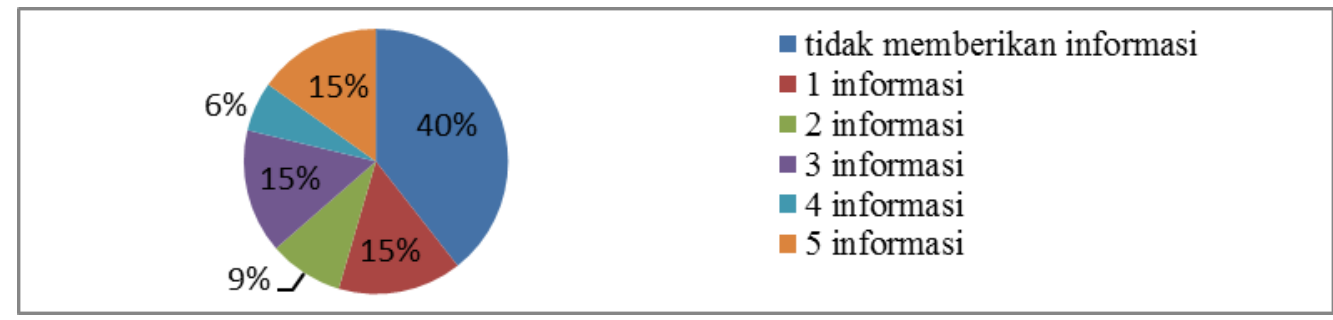

Gambar 4. Persentase peserta menurut jumlah informasi yang dikontribusikan pada kegiatan kaji terap budidaya padi toleran salinitas tahun 2019

Jumlah jenis biaya lain yang dikontribusikan dalam penelitian ini adalah biaya penyediaan/akses media yang dikeluarkan oleh anggota untuk berkomunikasi dengan stakeholder, seperti pembelian pulsa telepon. Hasil penelitian pada Gambar 5 menunjukkan bahwa sebagian besar para peserta kegiatan kaji terap budidaya salin sebanyak 22 orang (67 persen) tidak mengeluarkan biaya besar untuk akses komunikasi. Biaya akses komunikasi yang dikeluarkan oleh peserta rata-rata hanya 
mengeluarkan biaya rendah, yaitu sebesar Rp 20.000,00 sampai $\mathrm{Rp} 25.000,00$ (di bawah $\mathrm{Rp}$ $50.000,00)$ setiap bulannya untuk membeli pulsa telepon.

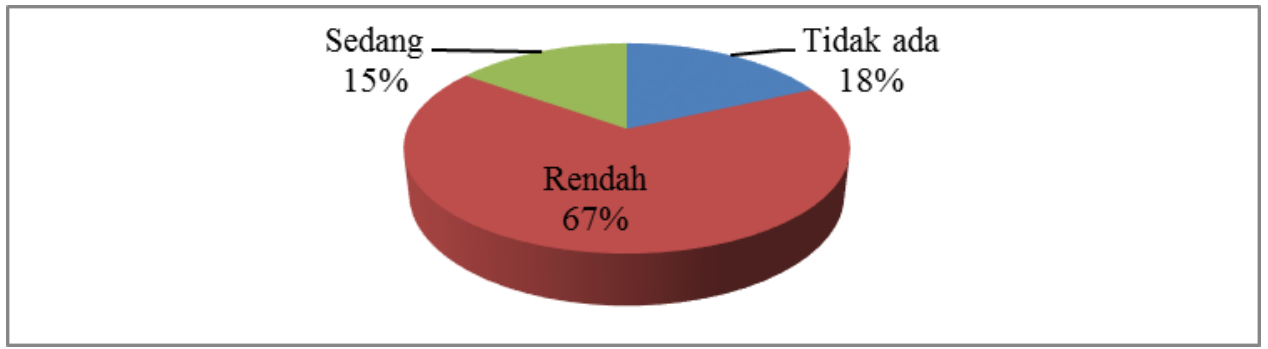

Gambar 5. Persentase peserta menurut jumlah jenis biaya lain yang dikontribusikan budidaya padi toleran salinitas tahun 2019

\begin{abstract}
Aksi Bersama
Aksi bersama adalah derajat saling ketergantungan yang terjadi di antara para peserta kegiatan kaji terap budidaya padi varietas toleran salinitas (Inpari 34 salin agritan) dalam bentuk pengambilan keputusan dan pelaksanaan kegiatan. Pada penelitian ini proses aksi bersama dilihat dari partisipasi individu, cara pengambilan keputusan, dukungan terhadap keputusan yang diambil, dukungan terhadap pelaksanaan kegiatan, dan keluaran dari hasil kegiatan kaji terap budidaya padi toleran salinitas. Hasil penelitian pada Tabel 1 menunjukkan bahwa mayoritas peserta kegiatan kaji terap sudah berpartisipasi secara aktif dalam diskusi dan pelaksanaan kegiatan kaji terap di lapang. Proses pengambilan keputusan lebih banyak diambil secara musyawarah mufakat dan perwakilan organisasi. Semua peserta kegiatan kaji terap selalu mendukung hasil keputusan dan pelaksanaan kegiatan kaji terap budidaya padi toleran salinitas. Keluaran dari hasil keputusan dalam diskusi di forum pertemuan dan pelaksanaan kegiatan kaji terap budidaya padi toleran salinitas untuk kalangan petani berupa tindakan langsung pelaksanaan kegiatan dan pengembangan kegiatan lanjutan. Berdasarkan informasi dari PPL pendamping kelompok tani kooperator bahwa pengembangan kegiatan lanjutan teknologi padi toleran salinitas telah dilakukan oleh petani kooperator dan petani lainnya seluas 85 hektar. Hal ini karena sudah terbukti adanya peningkatan hasil yang lebih baik dari sebelumnya dan kemudahan dalam menerapkan teknologi yang didiseminasikan dalam kegiatan kaji terap budidaya padi toleran salinitas. Keluaran berupa laporan lebih banyak dilaksanakan oleh pihak dari Dinas Pertanian Kabupaten Pangandaran, BPTP Jawa Barat, dan BPP Kecamatan Parigi.
\end{abstract}

Tabel 1. Jumlah dan persentase peserta menurut aksi bersama pada kegiatan kaji terap budidaya padi toleran salinitas tahun 2019

\begin{tabular}{|c|c|c|c|}
\hline \multirow{2}{*}{\multicolumn{2}{|c|}{ Indikator }} & \multicolumn{2}{|c|}{ Peserta Kegiatan Kaji Terap } \\
\hline & & Jumlah & Persentase \\
\hline \multicolumn{4}{|c|}{ Partisipasi di forum diskusi: } \\
\hline 1. & Tidak ikut & 6 & 18 \\
\hline 2. & Ikut, pasif & 7 & 21 \\
\hline 3. & Ikut, aktif & 20 & 61 \\
\hline \multicolumn{4}{|c|}{ Partisipasi pada pelaksanaan kegiatan: } \\
\hline 1. & Tidak ikut & 0 & 0 \\
\hline 2. & Ikut, kurang aktif & 11 & 33 \\
\hline 3. & Ikut, aktif & 22 & 67 \\
\hline \multicolumn{4}{|c|}{ Cara pengambilan keputusan: } \\
\hline 1. & sekelompok orang elit & 0 & 0 \\
\hline 2. & hanya perwakilan organisasi & 15 & 45 \\
\hline 3. & musyawarah dan mufakat & 18 & 55 \\
\hline \multicolumn{4}{|c|}{ Dukungan terhadap pelaksanaan kegiatan: } \\
\hline 1. & tidak & 0 & 0 \\
\hline 2. & ya & 33 & 100 \\
\hline \multicolumn{4}{|c|}{ Keluaran dari hasil kegiatan: } \\
\hline 1. & laporan & 5 & 15 \\
\hline
\end{tabular}




\begin{tabular}{clcc}
\hline & \multirow{2}{*}{ Indikator } & \multicolumn{2}{c}{ Peserta Kegiatan Kaji Terap } \\
\cline { 3 - 4 } & & Jumlah & Persentase \\
\hline 2. & kegiatan & 12 & 36 \\
3. & laporan dan kegiatan & 16 & 49 \\
\hline
\end{tabular}

Jaringan Komunikasi Kegiatan Kaji Terap Budidaya Padi Toleran Salinitas

Menurut (Bauer et al., 1982), jaringan komunikasi (communication networks) adalah suatu hubungan yang relatif stabil antara dua individu atau lebih yang terlibat dalam proses pertukaran informasi. Peran individu dalam jaringan menjadi bagian penting dalam analisis jaringan sosial, karena dapat membantu mengidentifikasikan individu-individu yang dianggap paling penting dalam sebuah jaringan sosial (Prell, 2011). Jaringan komunikasi pada kegiatan kaji terap budidaya padi salin merupakan interaksi yang terjadi antara individu yang terlibat pada kegiatan kaji terap budidaya padi salin dalam mencari dan berbagi informasi yang berkaitan dengan teknologi Pengelolaan Tanaman Terpadu (PTT) padi. Teknologi tersebut mencakup teknik budidaya, pemilihan dan perlakuan benih, pembuatan biochar, pemupukan, pengairan atau pencucian sawah, pengendalian hama dan penyakit (Tabel 2).

Tabel 2. Kepadatan dan sentralitas jaringan komunikasi kegiatan kaji terap budidaya padi toleran salinitas tahun 2019

\begin{tabular}{lclll}
\hline \multirow{2}{*}{ Materi diseminasi } & \multirow{2}{*}{ Kepadatan $(\%)$} & \multicolumn{3}{c}{ Sentralitas } \\
\cline { 3 - 5 } & & Popularitas & Kedekatan & Perantara \\
\hline Teknik budidaya padi salin & 9,56 & BPP & BPP & BPP \\
Pemilihan dan perlakuan benih & 8,43 & BPTP & BPTP & BPP \\
Pembuatan biochar & 8,33 & BPTP & BPTP & BPP \\
Cara pemupukan & 8,62 & BPTP & BPTP & BPP \\
Pengairan atau pencucian sawah & 8,90 & Kelompok & Kelompok & Kelompok \\
Pengendalian hama dan penyakit & 11,65 & tani & tani & tani \\
\hline
\end{tabular}

Densitas (kepadatan) adalah perbandingan jumlah link (ties) yang ada dalam jaringan dengan jumlah link yang mungkin muncul. Hasil penelitian pada Tabel 2 menunjukkan bahwa rata-rata hubungan yang ada dalam jaringan komunikasi kegiatan kaji terap budidaya padi salin pada kisaran sebesar 8,33 persen sampai 11,65 persen dari total potensi hubungan komunikasi yang mungkin terjalin. Hubungan yang terjadi dalam jaringan tersebut lemah karena nilai kepadatan pada jaringan rendah. Interaksi antaraktor dalam jaringan tersebut tidak merata ke semua aktor, hanya didominasi oleh aktor (individu) tertentu saja, sebagian besar peserta kegiatan kaji terap budidaya padi salin langsung berhubungan dengan sumber informasi perwakilan dari BPTP, BPP, dan kelompok tani. Penelitian Hertanto et al. (2016) tentang jaringan komunikasi dalam penerapan teknologi budidaya kentang juga menghasilkan nilai kepadatan jaringan rendah yang menandakan bahwa miskinnya hubungan komunikasi di antara petani dikarenakan sebagian besar petani langsung berhubungan dengan sumber informasi.

Sentralitas popularitas/lokal (degree centrality) adalah derajat di mana seorang individu berhubungan dengan individu lain dalam sistem. Sentralitas popularitas menunjukkan jumlah hubungan yang dapat dibuat individu dengan individu lain dalam sistem, menunjukkan popularitas aktor dalam jaringan sosial. Sentralitas kedekatan/global (closeness centrality) adalah derajat yang menunjukkan berapa jarak yang harus dilalui oleh individu tertentu untuk menghubungi semua individu di dalam sistem, menggambarkan seberapa dekat aktor (node) dengan semua aktor lain di dalam jaringan. Sentralitas perantara (betweenness centrality) merupakan pengukuran sentralitas yang mengukur sejauh mana individu tertentu terletak di antara individu-individu lain dalam suatu jaringan, menentukan aktor yang mengendalikan informasi atau aktor yang berperan sebagai fasilitator dalam menyebarkan informasi dalam suatu jaringan. 
Individu yang menjadi aktor sentral untuk sentralitas popularitas adalah Bapak PYA, Bapak SHN, Bapak DPN dan Bapak IDA. Individu yang menjadi aktor sentral untuk sentralitas kedekatan adalah Bapak PYA, Bapak SHN, dan Bapak IDA. Individu yang menjadi aktor sentral untuk sentralitas perantara adalah Bapak PYA dan Bapak IDA. Bapak PYA adalah Petugas Penyuluh Lapangan (PPL) dari BPP Kecamatan Parigi yang memiliki latar belakang pendidikan S-1 di bidang pertanian, berusia 29 tahun, pengalaman di bidang pertanian selama enam tahun, pernah mengikuti pelatihan padi organik, pupuk organik, manajemen pertanian, dan lainnya, berperan sebagai penanggungjawab untuk wilayah desa Cibenda dan pembina Kelompok Tani Sri Mukti yang menjadi petani kooperator pada kegiatan kaji terap budidaya padi salin. Bapak SHN adalah teknisi litkayasa dari BPTP Jawa Barat dengan latar belakang pendidikan D-3 pertanian, berusia 57 tahun, memiliki pengalaman di bidang pertanian selama 26 tahun semenjak menjadi PNS, sudah mengikuti banyak pelatihan di antaranya tentang sistem usaha tani terpadu, budidaya tanaman organik, dan pengendalian organisme pengganggu tanaman (OPT) terpadu. Bapak DPN adalah peyuluh dari BPTP Jawa Barat sebagai penanggungjawab kegiatan kaji terap budidaya padi toleran salinitas di Kabupaten Pangandaran, memiliki latar belakang pendidikan S-3 di bidang penyuluhan, berusia 45 tahun, pengalaman di bidang pertanian selama 20 tahun, dan mendapatkan pelatihan tentang teknik budidaya padi toleran salinitas dari Badan Penelitian Padi. Bapak IDA adalah bendahara di Kelompok Tani Sri Mukti, sudah lebih dari 35 tahun menjalani usaha tani dan pernah mengikuti pelatihan pengendalian hama dan penyakit tanaman. Keempat aktor sentral tersebut merupakan narasumber pada kegiatan kaji terap budidaya padi toleran salinitas.

\section{Efektivitas Komunikasi Stakeholder}

Efektivitas komunikasi stakeholder adalah keluaran yang diharapkan dari hasil koordinasi terkait kegiatan kaji terap budidaya padi varietas toleran salinitas (Inpari 34 salin agritan), meliputi kualitas informasi, kuantitas informasi, dan kepuasan dalam proses komunikasi. Kualitas informasi adalah kualitas materi informasi, meliputi kesesuaian terhadap kebutuhan (memberikan jalan keluar, bermanfaat, mudah diterapkan), tepat isi (informasi jelas, mudah dimengerti, akurat), dan tepat waktu (informasi terbaru, sesuai jadwal). Kualitas informasi inovasi yang disampaikan oleh para stakeholder pada kegiatan kaji terap budidaya padi toleran salinitas direspon positif oleh seluruh peserta kegiatan kaji terap karena sudah memenuhi kualitas yang diharapkan, yaitu sesuai kebutuhan, tepat isi, dan tepat waktu (Tabel 3). Varietas unggul padi Inpari 34 yang toleran salinitas terbukti memberikan hasil yang bagus sehingga lahan sawah yang selama ini selalu mengalami gagal panen jika terendam air asin karena padi yang ditanam sebelumnya tidak tahan terhadapa rendaman tersebut akhirnya dapat memberikan hasil setelah menggunakan varietas padi toleran salinitas.

Tabel 3. Persentase peserta terhadap persepsi kualitas informasi inovasi pada kegiatan kaji terap budidaya padi toleran salinitas tahun 2019

\begin{tabular}{|c|c|c|c|c|c|c|}
\hline \multirow[b]{2}{*}{ Informasi inovasi } & \multicolumn{6}{|c|}{ Kualitas Informasi Inovasi (\%) } \\
\hline & $\begin{array}{c}\text { Sesuai } \\
\text { kebutuhan }\end{array}$ & $\begin{array}{c}\text { Tepat } \\
\text { isi }\end{array}$ & $\begin{array}{l}\text { Tepat } \\
\text { waktu }\end{array}$ & $\begin{array}{c}\text { Sesuai } \\
\text { Kebutuhan } \\
\text { dan } \\
\text { tepat isi }\end{array}$ & $\begin{array}{c}\text { Sesuai } \\
\text { Kebutuhan } \\
\text { dan tepat } \\
\text { waktu }\end{array}$ & $\begin{array}{c}\text { Sesuai } \\
\text { Kebutuhan, } \\
\text { tepat isi dan } \\
\text { tepat waktu }\end{array}$ \\
\hline Teknik budidaya & 51,52 & 21,21 & 3,03 & 3,03 & 3,03 & 18,18 \\
\hline $\begin{array}{l}\text { Pemilihan dan } \\
\text { perlakuan benih }\end{array}$ & 27,27 & 45,45 & 3,03 & 3,03 & 0,00 & 21,21 \\
\hline $\begin{array}{l}\text { Pembuatan } \\
\text { biochar }\end{array}$ & 66,67 & 21,21 & 3,03 & 0,00 & 0,00 & 9,09 \\
\hline Cara pemupukan & 36,36 & 21,21 & 21,21 & 0,00 & 0,00 & 21,21 \\
\hline $\begin{array}{l}\text { Pengairan atau } \\
\text { pencucian sawah }\end{array}$ & 36,36 & 30,30 & 12,12 & 6,06 & 0,00 & 15,15 \\
\hline $\begin{array}{l}\text { Pengendalian } \\
\text { hama dan penyakit }\end{array}$ & 39,39 & 27,27 & 9,09 & 6,06 & 0,00 & 18,18 \\
\hline
\end{tabular}

Kuantitas informasi adalah persepsi stakeholder mengenai jumlah berbagai informasi yang diterima dan dibutuhkan stakeholder dari berbagai sumber atau berkaitan dengan kecukupan informasi, 
kekurangan informasi dan kelebihan informasi. Respon positif diberikan oleh peserta kegiatan kaji terap budidaya padi toleran salinitas terhadap kuantitas informasi inovasi yang disampaikan sumber informasi, tidak ada peserta yang memberikan respon negatif (tidak ada informasi dan kurang informasi). Informasi inovasi yang didiseminasikan pada kegiatan kaji terap budidaya padi toleran salinintas dinilai sudah cukup dan sangat lengkap oleh seluruh peserta (Tabel 4). Informasi inovasi tentang teknik budidaya, benih, pembuatan biochar, dan pengendalian hama dan penyakit sudah dirasakan cukup oleh sebagian besar peserta kegiatan kaji terap budidaya padi toleran salinitas (Tabel 4).

Tabel 4. Jumlah dan persentase peserta terhadap persepsi kuantitas informasi inovasi pada kegiatan kaji terap budidaya padi toleran salinitas tahun 2019

\begin{tabular}{lcccc}
\hline \multirow{2}{*}{\multicolumn{1}{c}{ Informasi inovasi }} & \multicolumn{4}{c}{ Kuantitas Informasi Inovasi } \\
\cline { 2 - 5 } & \multicolumn{2}{c}{ Cukup } & \multicolumn{2}{c}{ Sangat lengkap } \\
\cline { 2 - 5 } & Jumlah Peserta & Persentase & Jumlah Peserta & Persentase \\
\hline Teknik budidaya & 24 & 72,73 & 9 & 27,27 \\
Pemilihan dan perlakuan benih & 21 & 63,64 & 12 & 36,36 \\
Pembuatan biochar & 18 & 54,55 & 15 & 45,45 \\
Cara pemupukan & 15 & 45,45 & 18 & 54,55 \\
Pengairan atau pencucian sawah & 15 & 45,45 & 18 & 54,55 \\
Pengendalian hama dan penyakit & 26 & 78,79 & 7 & 21,21 \\
\hline
\end{tabular}

Tabel 5. Jumlah dan persentase peserta terhadap persepsi kepuasan dalam proses komunikasi pada kegiatan kaji terap budidaya padi toleran salinitas tahun 2019

\begin{tabular}{lcccc}
\hline \multirow{2}{*}{ Indikator } & \multicolumn{4}{c}{ Kepuasan dalam Proses Komunikasi } \\
\cline { 2 - 5 } & \multicolumn{2}{c}{ Cukup puas } & \multicolumn{2}{c}{ Sangat puas } \\
\cline { 2 - 5 } & Jumlah Peserta & Persentase & Jumlah Peserta & Persentase \\
\hline Partisipasi diskusi & 22 & 66,67 & 11 & 33,33 \\
$\begin{array}{l}\text { Partisipasi pelaksanaan kegiatan } \\
\text { Kemudahan komunikasi selama }\end{array}$ & 21 & 63,64 & 12 & 36,36 \\
$\begin{array}{l}\text { proses diskusi } \\
\text { Kemudahan komunikasi di }\end{array}$ & 18 & 54,55 & 15 & 45,45 \\
pelaksanaan kegiatan & 17 & 51,52 & 16 & 48,48 \\
$\begin{array}{l}\text { Berbagi informasi pada proses } \\
\text { diskusi }\end{array}$ & 19 & 57,58 & 14 & 42,42 \\
$\begin{array}{l}\text { Berbagi informasi pada } \\
\text { pelaksanaan kegiatan }\end{array}$ & 22 & 66,67 & 11 & 33,33 \\
\hline
\end{tabular}

Kepuasan dalam proses komunikasi adalah persepsi stakeholder mengenai kepuasan dalam partisipasi, kemudahan komunikasi dan berbagi ide/informasi dalam proses diskusi dan pelaksanaan kegiatan kaji terap budidaya padi toleran salinitas. Seluruh peserta kegiatan kaji terap budidaya padi toleran salinitas merespon positif terhadap proses komunikasi yang terjadi selama kegiatan kaji terap budidaya padi toleran salinitas, tidak ada peserta yang memberikan respon negatif (tidak puas dan kurang puas). Peserta sudah merasa cukup puas dan sangat puas dengan proses komunikasi untuk aspek partisipasi stakeholder di forum diskusi dan ketika pelaksanaan kegiatan di lapang, kemudahan dalam berkomunikasi dan berbagi informasi antarstakeholder selama proses diskusi dan pada saat kegiatan di lapang (Tabel 5).

Petani sebagai pelaku utama pada kegiatan di lapang selalu mendapat pendampingan dari stakeholder terkait, dan di forum diskusi tidak ada pembatasan saran, pendapat, dan masukan, semua peserta mendapatkan kebebasan menyampaikan pendapatnya. Komunikasi yang efektif yaitu selalu mengutamakan terjalinnya komunikasi melalui pertukaran informasi antarstakeholder, melakukan atau menjalin kerja sama dalam berbagai urusan atau program dan melakukan pembahasan melalui dialog 
atau simulasi untuk memecahkan permasalahan bersama (Purnomo, 2018). Jika koordinasi dan komunikasi dilakukan secara bersama-sama dengan baik, maka efektivitas komunikasi antarstakeholder juga akan meningkat (Enadarlita \& Asvio, 2019).

\section{Analisis Hubungan antara Karakteristik Media Komunikasi dan Penyimpanan Data dengan Efektivitas Komunikasi}

Penelitian ini menguji hubungan antara variabel karakteristik media komunikasi dan penyimpanan data dengan efektivitas komunikasi stakeholder pada kegiatan kaji terap budidaya padi toleran salinitas. Efektivitas komunikasi stakeholder meliputi kualitas informasi, kuantitas informasi dan kepuasan dalam proses. Indikator yang dianalisis untuk karakteristik media komunikasi dan penyimpanan data meliputi tingkat ketersediaan sarana dan prasarana pendukung komunikasi, dan jumlah penggunaan media komunikasi. Hasil uji korelasi rank Spearman menunjukkan terdapat hubungan nyata antara karakteristik media komunikasi dan penyimpanan data dengan efektivitas komunikasi (Tabel 6). Tingkat ketersediaan sarana dan prasarana pendukung komunikasi memiliki hubungan yang nyata negatif dengan kepuasan dalam proses komunikasi artinya semakin sedikit tingkat ketersediaan sarana dan prasarana pendukung, maka semakin memberikan kepuasan dalam proses komunikasi pada kegiatan kaji terap budidaya padi toleran salinitas.

Sebagian besar peserta kegiatan khususnya di kalangan petani hanya memiliki handphone yang bukan smartphone untuk alat komunikasi, mereka tidak menggunakan surat, email, faksimile, dan whatsapp selama berkomunikasi dalam kegiatan kaji terap budidaya padi toleran salinitas. Penggunaan handphone pada kegiatan kaji terap hanya digunakan oleh peserta dari instansi pemerintah (Dinas Pertanian, BPP, BPTP) untuk komunikasi di antara mereka, sedangkan dengan petani kooperator untuk penggunaan handphone hanya dilakukan oleh pengurus kelompok tani kooperator dengan PPL pendamping. Komunikasi dengan anggota lainnya tidak pernah menggunakan handphone, komunikasi banyak dilakukan dengan cara komunikasi tatap muka. Begitu juga untuk penggunaan surat, email, dan faksimile yang tidak pernah dilakukan untuk komunikasi di antara peserta kegiatan kaji terap budidaya padi toleran salinitas. Oleh karena itu forum pertemuan menjadi sarana prasarana utama karena semua peserta bersedia untuk hadir selama pelaksanaan kegiatan kaji terap budidaya padi toleran salinitas sehingga terjadi sosial konektivitas, di mana di antara mereka bisa saling berbagi informasi, mendapatkan solusi untuk permasalahan yang dihadapi terkait budidaya padi sehingga memberikan kepuasan dalam proses komunikasi di antara peserta.

Komunikasi tatap muka melalui berbagai pertemuan membuat komunikasi lebih efektif karena dapat langsung mendapatkan umpan balik dari semua peserta kegiatan kaji terap. Semua peserta dilibatkan dalam diskusi di forum pertemuan, tidak ada pembatasan saran dan masukan dari setiap peserta kegiatan kaji terap sehingga suasana diskusi aktif. Hasil penelitian Indraningsih (2017) juga menunjukkan bahwa model komunikasi yang efektif digunakan dalam diseminasi inovasi adalah yang bersifat interpersonal (tatap muka) yang mengedepankan interaksi yang dialogis (seperti demplot, temu lapang, pelatihan, dan pertemuan reguler). Nurfathiyah \& Rendra (2020) dari penelitiannya menunjukkan hasil yang sama bahwa penggunaan media lisan melalui ceramah dan diskusi efektif digunakan dalam kegiatan penyuluhan agar petani mau menerapkan sistem tanam jajar legowo.

Tabel 6. Nilai koefisien hubungan karakteristik media komunikasi dan penyimpanan data terhadap efektivitas komunikasi kegiatan kaji terap budidaya padi toleran salinitas tahun 2019

\begin{tabular}{|c|c|c|c|c|c|c|}
\hline \multirow{3}{*}{$\begin{array}{c}\text { Karakteristik Media } \\
\text { Komunikasi dan Penyimpanan } \\
\text { Data }\end{array}$} & \multicolumn{6}{|c|}{ Efektivitas Komunikasi $\left(r_{s}\right)$} \\
\hline & \multicolumn{2}{|c|}{$\begin{array}{l}\text { Kualitas } \\
\text { Informasi }\end{array}$} & \multicolumn{2}{|c|}{$\begin{array}{l}\text { Kuantitas } \\
\text { Informasi }\end{array}$} & \multicolumn{2}{|c|}{$\begin{array}{c}\text { Kepuasan dalam } \\
\text { Proses } \\
\text { Komunikasi } \\
\end{array}$} \\
\hline & $r_{\text {hit. }}$ & Sig. & $r_{\text {hit: }}$ & Sig. & $r_{\text {hit. }}$ & Sig. \\
\hline $\begin{array}{l}\text { Tingkat ketersediaan sarana dan } \\
\text { prasarana pendukung }\end{array}$ & $\begin{array}{c}- \\
0,070\end{array}$ & 0,698 & $-0,308$ & 0,081 & $-0,472 * *$ & 0,006 \\
\hline Jumlah media komunikasi & $-\overline{175}$ & 0,331 & $-0,257$ & 0,149 & $-0,362 *$ & 0,039 \\
\hline
\end{tabular}


Jumlah penggunaan media komunikasi terdapat hubungan nyata negatif dengan kepuasan dalam proses komunikasi (Tabel 6) artinya bahwa semakin sedikit jumlah media komunikasi yang digunakan, maka semakin memberikan kepuasan dalam proses komunikasi bagi peserta kegiatan kaji terap budidaya padi toleran salinitas. Penggunaan forum pertemuan untuk sosialisasi, bimbingan teknis, temu lapang, dan temu teknis menjadi media komunikasi utama yang digunakan oleh seluruh peserta selama kegiatan kaji terap. Materi informasi inovasi pada kegiatan kaji terap budaya padi toleran salinitas hanya disampaikan melalui komunikasi tatap muka, berupa forum pertemuan. Komunikasi tatap muka melalui forum pertemuan dilakukan sebanyak delapan kali selama kegiatan kaji terap budidaya padi toleran salinitas, di antaranya sosialisasi tiga kali, bimbingan teknis tiga kali, temu lapang satu kali, dan temu teknis satu kali.

Pada pertemuan untuk bimbingan teknis, materi diseminasi yang diberikan langsung dipraktikkan di lahan demplot sehingga peserta dapat lebih memahami, meningkatkan keterampilan karena selalu ikut terlibat setiap tahapan kegiatan dan hasilnya dapat langsung dilihat oleh semua peserta. Pendampingan juga selalu dilakukan oleh pihak BPTP Jawa Barat dan PPL BPP Kecamatan Parigi selama pelaksanaan kegiatan kaji terap budidaya padi toleran salinitas. Indikator kinerja fasilitator yang berpengaruh pada tingkat keberlanjutan adopsi inovasi adalah tingkat kunjungan (Suryani et al., 2017). Interaksi yang terjalin antara peserta kegiatan kaji terap berjalan baik. Pada setiap pertemuan juga tidak pernah membatasi setiap saran dan masukan dari peserta dan selalu ada solusi setiap permasalahan yang dihadapi di lapangan. Penggunaan media pertemuan tatap muka yang paling sering dilakukan dalam kegiatan tersebut memberikan hasil yang efektif dalam proses komunikasi. Hasil penelitian Fuady et al. (2012) menunjukkan bahwa komunikasi yang terjadi antara petani dan stakeholder terkait disebabkan oleh pihak stakeholder bersama-sama melakukan praktek langsung di lahan percontohan yang mudah diamati oleh petani. (Limenih, 2018) menemukan bahwa metode diseminasi inovasi yang dilakukan oleh penyuluh kepada petani lebih didominasi oleh kegiatan pelatihan, demonstrasi plot (demplot), dan diskusi dengan petani. Mardiyanto et al. (2020) juga membuktikan bahwa metode pelatihan, demplot, dan temu lapang secara signifikan berpengaruh terhadap efektivitas diseminasi budidaya bawang putih ramah lingkungan.

Tingkat ketersediaan sarana prasarana pendukung dan jumlah penggunaan media komunikasi tidak memiliki hubungan yang nyata dengan kualitas dan kuantitas informasi (Tabel 6). Komunikasi tatap muka melalui forum pertemuan menjadi satu-satunya media komunikasi yang digunakan untuk berinteraksi dengan seluruh peserta kegiatan kaji terap budidaya padi toleran salinitas, tetapi mampu memberikan informasi yang lengkap dan sesuai yang dibutuhkan petani sebagai pengguna inovasi. Kualitas dan kuantitas informasi inovasi tidak ditentukan dengan banyaknya sarana dan prasarana pendukung dan banyaknya media komunikasi yang digunakan dalam kegiatan kaji terap, tetapi oleh pemilihan media komunikasi yang tepat.

\section{Analisis Hubungan antara Karakteristik Individu dengan Efektivitas Komunikasi}

Penelitian ini menguji hubungan antara variabel karakteristik individu dengan efektivitas komunikasi stakeholder pada kegiatan kaji terap budidaya padi toleran salinitas. Hasil analisis menunjukkan bahwa indikator yang memiliki hubungan nyata dengan efektivitas komunikasi stakeholder adalah tingkat pendidikan formal, sedangkan yang tidak memiliki hubungan nyata, meliputi tingkat ketertarikan, pendidikan non formal, jumlah informasi, dan biaya akses yang dikeluarkan untuk melakukan komunikasi (Tabel 7). Tingkat pendidikan formal memiliki hubungan nyata negatif dengan kepuasan dalam proses komunikasi (Tabel 7) artinya bahwa semakin rendah tingkat pendidikan formal pada peserta kegiatan kaji terap budidaya padi toleran salinitas, maka semakin memberikan kepuasan dalam proses komunikasi. Semakin tinggi tingkat pendidikan formal peserta kegiatan kaji terap budidaya padi toleran salinitas, maka semakin tidak merasa puas dalam proses komunikasi.

Peserta yang berpendidikan formal rendah berasal dari kelompok tani kooperator yang berjumlah 18 orang (55 persen) dan sudah merasa sangat puas dengan interaksi para stakeholder yang terlibat pada

Jurnal Penyuluhan | Vol. 17 (01) 2021 | 96 
kegiatan kaji terap budidaya padi toleran salinitas. Hal ini karena anggota kelompok tani dapat dengan mudah berinteraksi dengan stakeholder dan selalu dapat memberikan solusi atas permasalahan yang dihadapi dalam menjalankan usaha tani. Peserta yang memiliki pendidikan formal tinggi berjumlah 15 orang (45 persen) berasal dari instansi pemerintah (BPTP, Dinas Pertanian, dan BPP) yang cenderung merasa hanya cukup puas dalam proses komunikasi pada kegiatan kaji terap budidaya padi toleran salinitas. Hal ini disebabkan karena tidak semua peserta kegiatan kaji terap budidaya padi toleran salinitas berpartisipasi aktif dalam forum diskusi dan pelaksanaan kegiatan di lapang. Peserta yang mengikuti forum diskusi tapi pasif sebanyak tujuh orang (21 persen) dan yang tidak mengikuti forum diskusi ada enam orang (18 persen), semuanya merupakan petani kooperator. Peserta yang kurang terlibat aktif dalam pelaksanaan kegiatan di lapang sebanyak sebelas orang (33 persen) merupakan petani kooperator. Hasil penelitian Narti (2015) menunjukkan bahwa terdapat hubungan yang nyata antara tingkat pendidikan petani yang mayoritas SMA dengan efektivitas komunikasi penyuluhan pertanian.

Tabel 7 Nilai koefisien hubungan karakteristik individu terhadap efektivitas komunikasi kegiatan kaji terap budidaya padi toleran salinitas tahun 2019

\begin{tabular}{lcccccc}
\hline \multirow{2}{*}{$\begin{array}{c}\text { Karakteristik Media } \\
\text { Komunikasi dan } \\
\text { Penyimpanan Data }\end{array}$} & \multicolumn{6}{c}{ Efektivitas Komunikasi $\left(\boldsymbol{r}_{\boldsymbol{s}}\right)$} \\
\cline { 2 - 7 } & \multicolumn{2}{c}{ Kualitas Informasi } & \multicolumn{3}{c}{ Kuantitas Informasi } & \multicolumn{2}{c}{ Kualitas Informasi } \\
\cline { 2 - 7 } & $\boldsymbol{r}_{\text {hit. }}$ & Sig. & $\boldsymbol{r}_{\text {hit. }}$ & Sig. & $\boldsymbol{r}_{\text {hit. }_{\text {. }}}$ & Sig. \\
\hline Tingkat ketertarikan & $-0,216$ & 0,228 & $-0,121$ & 0,501 & $-0,171$ & 0,342 \\
Tingkat pendidikan formal & $-0,232$ & 0,194 & $-0,214$ & 0,231 & $-0,389^{*}$ & 0,025 \\
Pendidikan non formal & $-0,132$ & 0,462 & 0,135 & 0,455 & 0,022 & 0,905 \\
Jumlah informasi & $-0,137$ & 0,446 & $-0,188$ & 0,294 & $-0,329$ & 0,061 \\
Biaya akses komunikasi & 0,038 & 0,834 & $-0,220$ & 0,218 & $-0,321$ & 0,068 \\
\hline
\end{tabular}

Keterangan: *berhubungan nyata pada $\alpha$ 0,05 (2-tailed)

Tingkat pendidikan formal tidak memiliki hubungan nyata dengan kualitas dan kuantitas informasi inovasi (Tabel 7). Hal ini karena semua sumber informasi memiliki latar belakang pendidikan formal yang beragam dari pendidikan rendah sampai tinggi. Informasi inovasi yang disampaikan oleh setiap sumber informasi jumlahnya beragam, dari yang hanya memberikan satu materi informasi inovasi sampai ada yang menyampaikan semua materi informasi inovasi yang didiseminasikan pada kegiatan kaji terap budidaya padi toleran salinitas. Indikator yang tidak memiliki hubungan nyata dengan efektivitas komunikasi stakeholder, meliputi tingkat ketertarikan, pendidikan non formal, jumlah informasi, biaya akses yang dikeluarkan untuk melakukan komunikasi (Tabel 7). Hal ini disebabkan karena ada tiga orang peserta kegiatan kaji terap budidaya padi toleran salinitas dari petani tertarik untuk memberikan sumber daya yang dimiliki hanya karena ingin memeroleh informasi saja, sebanyak 19 orang (58 persen) peserta belum pernah mengikuti pelatihan terkait budidaya padi, ada 13 orang (40 persen) peserta dari petani kooperator yang tidak ikut berkontribusi memberikan informasi terkait budidaya padi, sebagian besar peserta, yaitu sebanyak 22 orang (67 persen) mengeluarkan biaya yang tidak besar untuk akses komunikasi selama kegiatan kaji terap budidaya padi toleran salinitas, rata-rata besarnya Rp 20.000,00 sampai Rp 25.000,00 untuk membeli pulsa telepon, bahkan ada enam orang dari petani yang tidak perlu mengeluarkan biaya untuk akses komunikasi karena tidak memiliki telepon seluler.

\section{Analisis Hubungan antara Aksi Bersama dan Jaringan Komunikasi dengan Efektivitas Komunikasi}

Penelitian ini menguji hubungan antara variabel proses aksi bersama dan jaringan komunikasi dengan efektivitas komunikasi stakeholder pada kegiatan kaji terap budidaya padi toleran salinitas. Indikator yang dianalisis untuk jaringan komunikasi meliputi kepadatan, sentralitas popularitas, sentralitas kedekatan, sentralitas perantara. Hasil analisis menunjukkan bahwa indikator yang memiliki hubungan 
nyata dengan efektivitas komunikasi adalah kepadatan jaringan dan sentralitas kedekatan, sedangkan yang tidak memiliki hubungan nyata, meliputi proses aksi bersama, sentralitas popularitas, dan sentralitas perantara (Tabel 8).

Tabel 8. Nilai proses tindakan kolektif dan jaringan komunikasi terhadap efektivitas komunikasi kegiatan kaji terap budidaya padi toleran salinitas tahun 2019

\begin{tabular}{|c|c|c|c|c|c|c|}
\hline \multirow{3}{*}{$\begin{array}{c}\text { Proses Aksi Bersama } \\
\text { dan Jaringan } \\
\text { Komunikasi }\end{array}$} & \multicolumn{6}{|c|}{ Efektivitas Komunikasi $\left(r_{s}\right)$} \\
\hline & \multicolumn{2}{|c|}{ Kualitas Informasi } & \multicolumn{2}{|c|}{ Kuantitas Informasi } & \multicolumn{2}{|c|}{$\begin{array}{l}\text { Kepuasan dalam } \\
\text { Proses Komunikasi }\end{array}$} \\
\hline & $r_{\text {hit. }}$ & Sig. & $r_{\text {hit: }}$ & Sig. & $r_{\text {hit: }}$ & Sig. \\
\hline Aksi bersama & 0,005 & 0,980 & $-0,007$ & 0,968 & $-0,122$ & 0,500 \\
\hline Kepadatan jaringan & $-0,354^{*}$ & 0,043 & $-0,143$ & 0,427 & $-0,291$ & 0,101 \\
\hline Sentralitas popularitas & $-0,190$ & 0,290 & $-0,074$ & 0,684 & $-0,177$ & 0,325 \\
\hline Sentralitas kedekatan & $-0,362 *$ & 0,039 & $-0,047$ & 0,796 & $-0,063$ & 0,728 \\
\hline Sentralitas perantara & 0,107 & 0,554 & $-0,033$ & 0,854 & 0,028 & 0,879 \\
\hline
\end{tabular}

Keterangan: *berhubungan nyata pada $\alpha 0,05$ (2-tailed)

Kepadatan jaringan memiliki hubungan yang nyata negatif dengan kualitas informasi inovasi (Tabel 8), artinya bahwa nilai kepadatan jaringan yang rendah dalam jaringan komunikasi kegiatan kaji terap budidaya padi toleran salinitas, tetap dapat memberikan kualitas informasi inovasi yang baik. Nilai kepadatan jaringan rendah disebabkan karena para peserta hanya berinteraksi dengan star atau narasumber pada kegiatan kaji terap budidaya padi toleran salinitas sehingga informasi yang diberikan dapat memenuhi kualitas informasi inovasi yang diharapkan, yaitu informasi sesuai dengan kebutuhan, bermanfaat, memberikan jalan keluar, mudah diterapkan, mudah dimengerti, informasi terbaru, dan akurat. Individu yang berperan sebagai star adalah individu yang juga menjadi narasumber pada kegiatan kaji terap budidaya padi toleran salinitas. Mereka adalah perwakilan dari BPTP, yaitu Bapak SHN dan Bapak DPN, perwakilan dari BPP, yaitu Bapak PYA yang merupakan PPL pendamping kelompok tani kooperator, perwakilan dari petani, yaitu Bapak IDA merupakan bendahara kelompok tani kooperator. Hasil penelitian Gandasari et al. (2015) juga menunjukkan hasil yang sama bahwa densitas berhubungan nyata negatif dengan kualitas informasi. Semakin kecil nilai densitas maka semakin mandiri (interdependent) anggota aliansi dalam mencari informasi dan tidak tergantung kepada mediator.

Sentralitas kedekatan/closeness centrality digunakan untuk mengetahui seberapa jauh informasi menyebar dari satu aktor ke aktor lain dalam suatu jaringan. Sentralitas kedekatan memiliki hubungan yang nyata negatif dengan kualitas informasi inovasi (Tabel 8) artinya bahwa semakin kecil derajat sentralitas kedekatan akan meningkatkan kualitas informasi inovasi yang didiseminasikan pada kegiatan kaji terap budidaya padi toleran salinitas. Informasi yang berkualitas memenuhi salah satu dari kriteria yang diberikan, yaitu sesuai kebutuhan (memberikan jalan keluar, bermanfaat, mudah diterapkan), tepat isi (informasi jelas, mudah dimengerti, akurat), tepat waktu (informasi terbaru, sesuai jadwal).

Pada sentralitas kedekatan, makin kecil nilainya maka akan semakin baik. Nilai yang kecil memperlihatkan dekatnya aktor (node) dengan aktor lain dalam suatu jaringan (Eriyanto, 2014). Nilai sentralitas kedekatan yang kecil menunjukkan bahwa individu tersebut memiliki jarak paling pendek untuk menghubungi atau dihubungi oleh individu lain maka akan semakin mudah dalam berinteraksi dan menyebarkan informasi dalam jaringan komunikasi dari individu satu ke individu yang lain. Individu yang memiliki jarak paling pendek dari hasil penelitian adalah individu yang juga menjadi star dan berperan sebagai narasumber pada kegiatan kaji terap budidaya padi salin, yaitu Bapak SHN perwakilan dari BPTP, Bapak PYA perwakilan dari BPP merupakan PPL pendamping kelompok tani kooperator, dan Bapak IDA merupakan bendahara kelompok tani kooperator. Oleh karena itu mereka memiliki kemudahan dalam berkomunikasi dengan peserta lain karena memiliki kedekatan dari aspek jarak dengan peserta lainnya pada kegiatan kaji terap budidaya padi toleran salinitas, sehingga 
informasi yang disampaikan memenuhi aspek kualitas informasi, yaitu bisa cepat diterima, jelas, akurat, dan sesuai kebutuhan.

Hal ini sejalan dengan penelitian Rahmawati (2017) yang menemukan sentralitas kedekatan berhubungan nyata negatif dengan penerapan sistem tanam jajar legowo, ini berarti semakin rendah sentralitas kedekatan maka tingkat penerapan sistem tanam jajar legowo semakin tinggi. Hasil penelitian ini sejalan dengan Hertanto et al. (2016) yang menemukan juga hubungan yang nyata antara sentralitas kedekatan dengan penerapan teknologi budidaya kentang, interaksi komunikasi dengan aktor yang jaraknya saling berdekatan dapat mempercepat proses penerapan teknologi budidaya kentang karena akan mengurangi ketidakpastian informasi dan selanjutnya akan mampu menerapkan teknologi budidaya sesuai anjuran. Hasil yang berbeda ditunjukkan pada penelitian Rahmawati et al. (2016) bahwa sentralitas kedekatan tidak memiliki hubungan nyata dengan efektivitas diseminasi informasi penanaman dan pemeliharaan jeruk Pamelo karena petani sudah menguasai teknik penanaman dan pemeliharaan yang diperoleh secara turun temurun dari orangtua dan pengalaman bukan dari proses komunikasi dengan aktor sentral dalam jaringan.

Kepadatan jaringan dan sentralitas kedekatan tidak memiliki hubungan nyata dengan kuantitas informasi inovasi dan kepuasan dalam proses komunikasi (Tabel 8). Hal ini karena nilai kepadatan jaringan yang rendah dalam jaringan komunikasi pada kegiatan kaji terap budidaya padi toleran salinitas menggambarkan interaksi komunikasi antara peserta rendah sehingga pertukaran informasi yang terjadi juga rendah, jumlah informasi yang menyebar dari satu individu ke individu lainnya sedikit karena interaksi yang terjadi hanya dengan individu tertentu perwakilan dari BPTP, BPP, dan kelompok tani. Interaksi komunikasi antara peserta yang rendah juga menunjukkan bahwa ada individu perwakilan BPTP yang tidak dapat selalu hadir mendampingi petani kooperator ketika pelaksanaan kegiatan di lapang karena terkendala jarak tempat tinggal yang jauh dari lokasi kegiatan sehingga mengurangi nilai kepuasan dalam proses komunikasi dengan peserta lainnya.

Indikator yang tidak memiliki hubungan nyata dengan efektivitas komunikasi stakeholder, meliputi proses aksi bersama, sentralitas popularitas, dan sentralitas perantara (Tabel 8). Peserta kegiatan kaji terap budidaya padi toleran salinitas sebagian besar hanya berpartisipasi pasif ketika proses aksi bersama dalam pengambilan keputusan, hanya menerima saja hasil keputusan. Pada sentralitas popularitas yang menjadi sumber informasi utama pada kegiatan kaji terap budidaya padi toleran salinitas adalah individu perwakilan dari BPTP yang frekuensi kehadirannya tidak banyak karena faktor jarak tempat tinggal yang jauh, waktu, dan anggaran yang tidak mencukupi untuk selalu turun lapang sehingga interaksinya sedikit dengan petani. Petani lebih sering didampingi oleh PPL. Sentralitas perantara atau yang menjadi mediator pada kegiatan kaji terap budidaya padi toleran salinitas adalah individu perwakilan dari BPP, yaitu PPL pendamping kelompok tani kooperator, tetapi bukan menjadi sumber informasi utama pada kegiatan kaji terap budidaya padi toleran salinitas, dan yang paling banyak menghubunginya hanya dari anggota kelompok tani kooperator dengan peserta lain interaksinya kurang intensif.

\section{KESIMPULAN}

Komunikasi stakeholder pada kegiatan kaji terap budidaya padi toleran salinitas sudah cukup efektif, informasi inovasi yang didiseminasikan sudah dirasakan cukup, sesuai kebutuhan, tepat isi dan tepat waktu oleh peserta. Proses komunikasi yang terjadi antara pemangku kepentingan selama pelaksanaan kegiatan sudah cukup puas dirasakan oleh sebagian besar peserta. Variabel-variabel yang berhubungan nyata dengan efektivitas komunikasi stakeholder untuk kepuasan dalam proses komunikasi adalah variabel karakteristik media komunikasi, meliputi tingkat ketersediaan sarana prasarana pendukung komunikasi, dan jumlah penggunaan media komunikasi, dan variabel karakteristik individu, yaitu tingkat pendidikan formal. Variabel yang berhubungan nyata dengan efektivitas komunikasi stakeholder untuk kualitas informasi adalah jaringan komunikasi, yaitu kepadatan jaringan dan sentralitas kedekatan. Komunikasi tatap muka melalui berbagai forum pertemuan menjadi media komunikasi yang efektif digunakan dalam kegiatan kaji terap budidaya padi toleran salinitas. Belum ada media penyimpanan data yang dapat diakses oleh seluruh peserta kegiatan kaji terap budidaya padi toleran salinitas. Kepadatan jaringan pada jaringan sosial kegiatan kaji terap budidaya padi toleran 
salinitas rendah karena para peserta hanya berinteraksi dengan star atau sumber informasi pada kegiatan kaji terap budidaya padi toleran salinitas. Aktor sentral pada jaringan sosial kegiatan kaji terap budidaya padi toleran salinitas ada empat orang, yaitu dua orang dari BPTP Jawa Barat, satu orang dari BPP Kecamatan Parigi, dan satu orang dari Kelompok Tani Sri Mukti. Kemampuan individu dalam mencari informasi secara mandiri tanpa bergantung dengan mediator dan semakin dekat jarak antara individu dengan individu lain atau dengan sumber informasi untuk berinteraksi dalam kegiatan kaji terap budidaya padi toleran salinitas dapat menghasilkan komunikasi yang efektif.

\section{DAFTAR PUSTAKA}

Balitbangtan. (2015). Rencana Strategis Badan Penelitian dan Pengembangan Pertanian Tahun 20152019. Badan Penelitian dan Pengembangan Pertanian.

Bauer, J., Rogers, E. M., \& Kincaid, D. L. (1982). Communication Networks: Toward a New Paradigm for Research. Social Forces. https://doi.org/10.2307/2578109

BBP2TP. (2018). Pedoman Pelaksanaan Peningkatan Kapasitas Penyuluh dan Diseminasi Inovasi Pertanian.

Enadarlita, \& Asvio, N. (2019). Pengaruh koordinasi dan komunikasi terhadap efektivitas organisasi di Provinsi Jambi. 4(1), 34-42. https://jurnal.univpgripalembang.ac.id/index.php/JMKSP/article/view/2473/2303

Eriyanto. (2014). Analisis Jaringan Komunikasi. Perpustakaan Nasional: Katalog Dalam Terbitan (KDT). https://doi.org/10.1017/CBO9781107415324.004

Fuady, I., Lubis, D. P., \& Lumintang, R. W. (2012). Perilaku komunikasi petani dalam pencarian informasi pertanian organik (kasus petani bawang merah di Desa Srigading Kabupaten Bantul). Jurnal Komunikasi Pembangunan, 10(2), 10-18. http://journal.ipb.ac.id/index.php/jurnalkmp/article/view/9065/7128

Gandasari, D., Sarwoprasodjo, S., Ginting, B., \& Susanto, D. (2015). Model sistem informasi komunikasi antarorganisasi pada konsorsium anggrek di Indonesia. Jurnal Agro Ekonomi, 33(1), 35-50. https://doi.org/10.21082/jae.v33n1.2015.35-50

Hertanto, D., Sugiyanto, S., \& Safitri, R. (2016). Analisis struktur jaringan komunikasi dan peran aktor dalam penerapan teknologi budidaya kentang (petani kentang Desa Ngantru Kecamatan Ngantang Kabupaten Malang). Habitat, 27(2), 55-65. https://doi.org/10.21776/ub.habitat.2016.027.2.7

Indraningsih, K. S. (2011). Pengaruh penyuluhan terhadap keputusan petani dalam adopsi inovasi teknologi usahatani terpadu. Forum Penelitian Agro Ekonomi, 29(1), 1-24. https://doi.org/10.21082/jae.v29n1.2011.1-24

Indraningsih, K. S. (2017). Strategi diseminasi inovasi pertanian dalam mendukung pembangunan pertanian. Forum Penelitian Agro Ekonomi, 35(2), 107-123. https://doi.org/http://dx.doi.org/10.21082/fae.v35n2.2017.107-123

Kallo, R., \& Sariubang, M. (2013). Spillover teknologi berbasis Spektrum Diseminasi Multi Chanel (SDMC) (studi kasus: proses difusi inovasi teknologi pada program m-P3MI di Kabupaten Pinrang, Propinsi Sulawesi Selatan). Jurnal AgroSainT, V(1), 48-53. journals.ukitoraja.ac.id > index.php > agro > article > download

Limenih, B. (2018). Agricultural knowledge, source and information system in central highland of Ethiopia. Journal of Agricultural Extension and Rural Development, 10(2), 28-34. https://doi.org/10.5897/jaerd2017.0908

Mardiyanto, T. C., Samijan, \& Nurlaily, R. (2020). Efektivitas metode penyuluhan dalam desiminasi budidaya bawang putih ramah lingkungan di Kabupaten Karanganyar. Jurnal Triton, 11(1), 4557. http://jurnal.polbangtanmanokwari.ac.id

Monge, P. R., Fulk, J., Kalman, M. E., Flanagin, A. J., Parnassa, C., \& Rumsey, S. (1998). Production of Collective Action in Alliance-Based Interorganizational Communication and Information Systems. Organization Science, 9(3), 411-433. https://doi.org/10.1287/orsc.9.3.411

Narti, S. (2015). Hubungan karakteristik petani dengan efektivitas komunikasi penyuluhan pertanian 
dalam program SL-PTT (kasus kelompok tani di Kecamatan Kerkap Kabupaten Bengkulu $\begin{array}{llll}\text { Utara). Jurnal Professional } & \text { FIS }\end{array}$ https://doi.org/https://doi.org/10.37676/professional.v2i2.173

Nurfathiyah, P., \& Rendra. (2020). Efektivitas media dan materi penyuluhan dalam penerapan sistem tanam jajar legowo di Kecamatan Sakernan Kabupaten Muaro Jambi. Jurnal Ilmiah Ilmu Terapan Universitas Jambi, 4(1), 59-73. journal.unja.ac.id/JIITUJ/article/view/9850

Prawiranegara, D. (2019). Peningkatan komunikasi, koordinasi dan diseminasi hasil inovasi teknologi di Jawa Barat.

Prell, C. (2011). Social Network Analysis: History, Theory and Methodology. In Social network theory and educational change.

Purnomo, A. (2018). Pelaksanaan kebijakan komunikasi organisasi pemerintahan di Indonesia. Jurnal Noken: Ilmu-Ilmu Sosial, 3(2), 11-26. https://doi.org/10.33506/jn.v3i2.111

Rahmawati. (2017). Peran jaringan komunikasi spektrum diseminasi multi channel dalam pengelolaan tanaman terpadu padi di Kabupaten Lombok Tengah. Institut Pertanian Bogor.

Rahmawati, A., Muljono, P., \& Sarwoprasodjo, S. (2016). Analisis jaringan komunikasi dalam diseminasi informasi produksi dan pemasaran jeruk Pamelo. Jurnal Komunikasi Pembangunan, 14(1), 1-12. https://doi.org/https://doi.org/10.29244/jurnalkmp.14.1.\%25p

Sarwani, M., Jamal, E., Subagyono, K., Sirnawati, E., \& Hanifah, V. W. (2011). Diseminasi di BPTP: pemikiran inovatif transfer teknologi spesifik lokasi. Jurnal Pertanian Indonesia, 9(1), 73-89. https://doi.org/http://dx.doi.org/10.21082/akp.v9n1.2011.73-89

Silalahi, U. (2015). Metode Penelitian Sosial Kuantitatif. Journal of Visual Languages \& Computing.

Suryani, A., Fatchiya, A., \& Susanto, D. (2017). Keberlanjutan penerapan teknologi pengelolaan pekarangan oleh wanita tani di Kabupaten Kuningan. Jurnal Penyuluhan, 13(1), 50-63. https://doi.org/10.25015/penyuluhan.v13i1.14641

Syakir, M. (2016). Pemantapan inovasi dan diseminasi teknologi dalam memberdayakan petani. Prosiding Seminar Nasional Perlindungan Dan Pemberdayaan Pertanian Dalam Rangka Pencapaian Kemandirian Pangan Nasional Dan Peningkatan Kesejahteraan Petani, 3-14. http://pse.litbang.pertanian.go.id/ind/pdffiles/prosiding_2016/0_1.pdf

Tarigan, H., Suhaeti, R. N., \& Rivai, R. S. (2016). Strategi komunikasi pemanfaatan varietas unggul baru padi toleran rendaman. Analisis Kebijakan Pertonian, 14(2), 97-112. https://doi.org/http://dx.doi.org/10.21082/akp.v14n2.2016.97-112 